\title{
The Enigma of Samuel Parsons Scott
}

\author{
Timothy G. Kearley*
}

Abstract - Samuel Parsons Scott (1846-1929) single-handedly translated into English the Corpus Juris Civilis, the Visigothic Code, and the Siete Partidas. The last of these was very well received and not long ago reprinted in a new edition. The translation of the Corpus Juris Civilis, published as The Civil Law (1932), was criticized strongly but has been consulted frequently because, until recently, it contained the only published English translation of Justinian's Code. Almost nothing has been known about Scott himself, as he was an independent scholar who lived and worked in the small American town of Hillsboro, Ohio. This article uses information obtained from Hillsboro newspapers, local histories, probate court records, and the catalog of Scott's personal library, to describe his life and the details of his work. It proposes an explanation for why he went from being a successful smalltown business man, who wrote about history and his travels as an avocation, to being a recluse who devoted his last years to translating ancient laws. The article's analysis of Scott and his library also suggests some possible explanations for the flaws in his translation of the Justinianic Corpus.

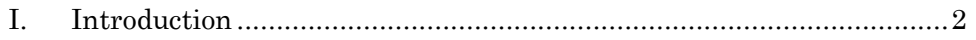

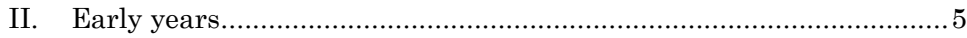

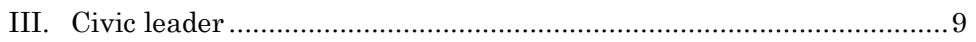

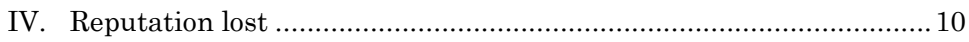

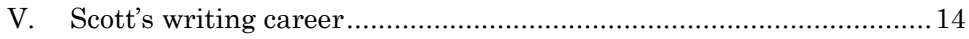

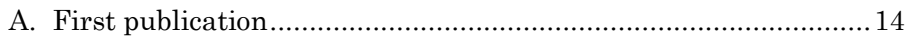

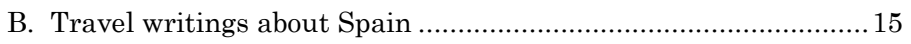

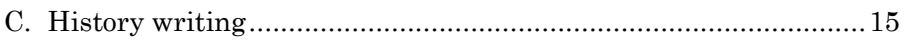

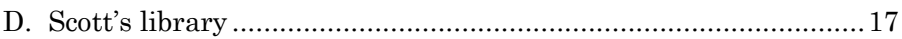

* Professor Emeritus of Law, University of Wyoming.

Roman Legal Tradition, 10 (2014), 1-37. ISSN 1943-6483. Published by the Ames Foundation at the Harvard Law School and the University of Glasgow School of Law. This work may be reproduced and distributed for all non-commercial purposes. Copyright @ 2014 by Timothy G. Kearley. All rights reserved apart from those granted above. ROMANLEGALTRADITION.ORG 


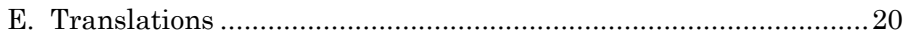

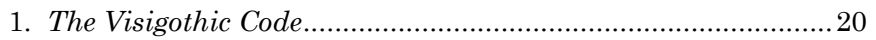

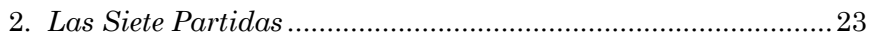

3. The Civil Code and other translations......................................26

a. Other translations .......................................................... 26

b. Scott's death and surrounding intrigue.............................26

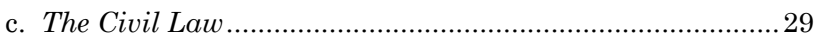

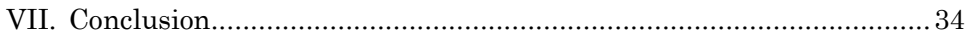

Appendix 1. Writings of Samuel P. Scott

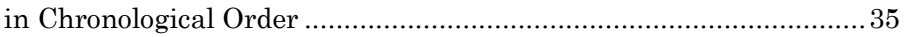

Appendix 2. Translations of Justinianic

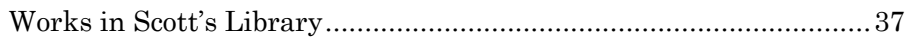

\section{Introduction}

Samuel Parsons Scott (1846-1929) has been a mysterious figure. $\mathrm{He}$ is the lone translator of the entire Justinianic corpus into English, ${ }^{1}$ translator also of the Visigothic Code $^{2}$ and of the Siete Partidas, ${ }^{3}$ and author of Through Spain ${ }^{4}$ and History of the Moor-

1 The Civil Law, ed. and trans. S. P. Scott (Cincinnati 1932; repr. New York 1973) (hereafter The Civil Law). In 2015 or early 2016, the Cambridge University Press is scheduled to publish a new English translation of the Codex created by a panel led by Bruce Frier, and founded on Justice Fred H. Blume's translation. (Blume's version can be found at "Annotated Justinian Code," George W. Hopper Law Library, University of Wyoming (website).) A new English translation of the Novellae Constitutiones from the Greek, by David J. D. Miller and Peter Sarris, and also to be published by the CUP, is in progress. Blume's version of the Novels, based on the Latin of Schoell and Kroll, is at "Justinian Novels," George W. Hopper Law Library, University of Wyoming (website). For an English translation of the Digest, see The Digest of Justinian, ed. T. Mommsen, P. Krueger, and A. Watson (Philadelphia 1985; English-only, with corrections, Philadelphia 1998), and for the Institutes see Justinian's Institutes, trans. P. Birks and G. McLeod (Ithaca 1987) (with the Latin text of Paul Krueger).

2 The Visigothic Code (Forum Judicum), ed. and trans. S. P. Scott (Boston 1910; repr. Littleton 1982) (hereafter The Visigothic Code).

3 Las Siete Partidas, ed. and trans. S. P. Scott (Chicago 1931; repr. with modifications Philadelphia 2001) (hereafter Las Siete Partidas).

4 S. P. Scott, Through Spain: A Narrative of Travel and Adventure in the Peninsula (Philadelphia and London 1886). 
ish Empire in Europe, ${ }^{5}$ all of which have been reprinted since his death - some more than once. ${ }^{6}$ He also wrote many magazine articles (all but one about his travels in Spain) ${ }^{7}$ and was a founding, long-serving editorial staff member of the American Bar Association's Comparative Law Bureau. ${ }^{8}$ At the time of Scott's death, the Bureau also held two more of his translations that it never published. ${ }^{9}$ Yet, when I undertook to learn about S. P. Scott, the only readily available sources of biographical information were a brief German Wikipedia entry ${ }^{10}$ and a short sketch on the Thomas Jefferson University website in connection with an explanation of how he came to endow the university's Scott Memorial Library. ${ }^{11}$

Why has such a prolific, still-read scholar remained so obscure a person? One reason may be that his translations of the Visigothic Code and of Justinian's compilations received some

5 S. P. Scott, History of the Moorish Empire in Europe (Philadelphia 1904; repr. New York 1977) (hereafter History).

6 In recent years several print-on-demand publishers have advertised reprints of some of Scott's works, e.g., Through Spain (note 4) (the British Library, Historical Print Editions series), and History (note 5) (Nabu Press 2010; Forgotten Books 2012).

7 See Appendix 1 for a chronological list.

8 C. S. Lobingier, "Samuel Parsons Scott, 1846-1929," A.B.A. J., 15 (1929), 529.

9 Lobingier states that Scott's The Visigothic Code was "the first of a series of translations by him of Spanish legal collections whose publication would be of immense value to the science of comparative law." Id. An earlier report on the Bureau's work says: "Your Secretary has in hand the manuscripts for the following: 1. Las Siete Partidas; 2. The Laws of Ancient Castille; 3. The Criminal Code of Spain. These three last translations have been made by Mr. S. P. Scott, of Hillsboro, Ohio, and have been donated by him to the Bureau." "Proceedings of the Comparative Law Bureau," Ann. Report A.B.A., 38 (1915), 882, 883.

10 "Samuel Parsons Scott," in Wikipedia: Die freie Enzyklopädie (website). I subsequently wrote a longer entry on Mr. Scott in the English-language Wikipedia. It is interesting to note, as an indication of the esteem in which Scott is held by many Muslims due to the high regard he expressed for Islam in History of the Moorish Empire, that this Wikipedia entry was posted in whole (with attribution) in the online Muslim Times (June 29, 2014) as "Samuel Parsons Scott: A Gentleman and a Scholar" with the subtitle "Muhammad: the Light for the Dark Ages of Europe." See Zia Shah, "Samuel Parsons Scott: A Gentleman and a Scholar," The Muslim Times (June 2014) (website). See also note 94 and accompanying text.

11 M. Angelo, "Gesundheit: The Story of Scott Memorial Library," University Archives and Special Collections, Thomas Jefferson University (website). 
harsh criticism. ${ }^{12}$ On the other hand, his Las Siete Partidas was rather well-received and was reprinted by the University of Pennsylvania Press in 2001.13 Perhaps more importantly, S. P. Scott was a gentleman-scholar who lived most of his life in the small town of Hillsboro, Ohio, and who became reclusive in the last two to three decades of his life. ${ }^{14} \mathrm{He}$ also appears not to have established significant relationships with other scholars through correspondence or travel to professional meetings. Moreover, Scott had no children and was bitterly estranged from his wife at the time of his death. ${ }^{15}$ This absence of fond family members or close colleagues may have aided his passage into relative obscurity soon after his death.

Because I have written about Scott's contemporary, and fellow translator of the Justinian's Codex, Justice Fred H. Blume, ${ }^{16}$ I was intrigued by this dearth of information about Scott. (As will be seen in what follows, I also found highly informative certain points of comparison between them.) In particular, I wondered how Scott went so far astray in some of his translations, when Blume did not, even though both were independent scholars. As I learned more about Scott, I also began to be curious about why he went from being a leading citizen to a little-liked recluse in his hometown of Hillsboro. By combing local resources in Hillsboro, including probate court records and newspapers, searching extensively on the web for reviews and references to his work, and following part of Scott's extensive personal library to Thomas Jefferson University and Bucknell University, I have been able to answer these questions to a significant extent. In some respects, S. P. Scott's life was the stuff of melodrama, involving a bank failure, withdrawal from society, a claim on his estate by a longtime secretary, and the occult. In what follows, I present a fuller, if still grainy and inevitably incomplete, picture of Samuel Parsons Scott and his work.

12 See notes 116-125 and accompanying text, and notes 172-173, 180-181 and accompanying text, respectively.

13 See notes 139-145 and accompanying text.

14 See notes 57-86 and accompanying text, in particular.

15 His will refers to the "insults, outrages, cruelties, disgrace and humiliation which she has constantly and without reason, during my entire married life, heaped upon me." See "Item 1," Samuel P. Scott Will (Nov. $16,1925)$ (unpublished manuscript) (digital image on file with the author).

16 T. G. Kearley, "Justice Fred Blume and the Translation of Justinian's Code," Law Libr. J., 99 (2007), 525; see also "Annotated Justinian Code" (note 1). 


\section{Early years}

Samuel Parsons Scott was born in Hillsboro on July 8, 1846, to William Scott and Elizabeth Jane Parsons Scott. William Scott was well-educated, practiced law in Hillsboro, and eventually prospered financially through brokerage and money-lending. ${ }^{17}$ Around 1835, William Scott commissioned the same architect who designed the Highland County courthouse to create for him a handsome home in the federal style. ${ }^{18}$ In 1843, William married Elizabeth Jane Parsons, the daughter of an influential Columbus, Ohio physician, Samuel Parsons. Three years later, Elizabeth gave birth to a son, Samuel Parsons Scott, and then, in 1856, to a daughter, Jane Elizabeth Scott. ${ }^{19}$ According to one source, William was an abolitionist and during the American Civil War equipped a Hillsboro cavalry company called the Scott Dragoons. ${ }^{20}$ A county history indicates young Samuel attended Hillsboro schools. $^{21}$ It is likely this included The Academy, which had a classics-based curriculum. ${ }^{22}$

A lengthy description of the history of education in the United States is well beyond the scope of this paper, but it is important to note that a classics-based education was common in Scott's time for the sons of wealthy families, even in a small town such as Hillsboro. ${ }^{23}$ The "Latin schools," which had been the predominate educational institution for boys of the affluent in the United States from colonial times, yielded in the mid-1700s to "academies."24 These church-based, or subscription-based, academies proliferated for the next 70 years or so, with some 6,000 of them existing in 1850 when Scott was four years old. ${ }^{25}$ The Ohio

17 J. W. Klise and A. E. Hough, The County of Highland: A History of Highland County Ohio, from the Earliest Days (Madison 1902), 467.

18 "The History of the Scott House," Highland County Historical Society, Highland Country, Ohio (website). The Scott House, now owned by the Highland County Historical Society, is rumored to have been a stop on the Underground Railroad. Id.

19 E. J. Ayers, Highland Pioneer Sketches and Family Genealogies (Springfield 1971), 206-207.

20 Klise and Hough (note 17), 467.

21 Ayers (note 19), 206. See also Klise and Hough (note 17), 211.

22 E. J. Ayers, The Hillsboro Story (Springfield 1957), 32.

23 See R. F. Butts and L. A. Cremin, A History of Education in American Culture (New York 1953), 75, 121; E. P. Cubberley, Public Education in the United States (Boston 1919), 23-24.

24 Compare Cubberley (note 23), 40 (by 1750 Latin schools had given way to academies) with Butts and Cremin (note 23), 260 (the academy movement began in 1780).

25 Butts and Cremin (note 23), 260. 
legislature had authorized a system of county-based academies in the early 1800 s. $^{26}$ The academies did not provide as intense instruction in Latin and Greek as the Latin schools, given that the latters' function was to prepare students to meet Harvard College's strict admission requirements concerning those languages. $^{27}$ The academies, on the other hand, "retained the study of Latin, and usually Greek but through the medium of English." 28

It seems likely that Samuel's father, as a wealthy, leading citizen of Hillsboro, would have subscribed to the Hillsboro Academy, which had been founded in 1827 during the flood tide of the academies movement. ${ }^{29}$ A two-story brick building was built for the Academy in 1845, and its reputation for a sound education in "the higher branches" is said to have been secured through the talents of "Professor" Isaac Sams. Sams taught classes in mathematics, classics, and English. ${ }^{30}$ Another indication that Samuel Parsons Scott attended the Academy is that he would have needed a classical preparatory education to be admitted to Miami University (in Oxford, Ohio), from which he graduated in 1866 with an A.B. degree, as class valedictorian, and a member of Phi Beta Kappa. ${ }^{31}$ According to a contemporary publication of Miami

26 Cubberley (note 23), 78-79; G. W. Knight, "History of Educational Progress in Ohio," in H. Howe, ed., Historical Collections of Ohio in Two Volumes, an Encyclopedia of the State, 1 (Cincinnati 1907), 137, available at The Internet Archive (website). Regarding the academies movement in Ohio, Knight says: "The [Ohio] Constitution of 1802 provided for the establishment of academies and colleges by corporations of individuals, and from that time until 1838 public sentiment appears to have crystallized into the idea that private seminaries were the proper and only necessary means for attaining an education higher than that of the common school .... Accordingly in many places academies were started, either as private enterprises or under the general sanction and control of religious sects." Id., 143.

27 Students admitted to Harvard in its early years had to "understand Tully, or suchlike classical Latin authors extempore and make and speake true Latin in verse and prose ... and declare perfectly the paradigms of nounes and verbes in the Greek tonge." Cubberley (note 23), 28 (quoting the original, 1642, admission requirements of Harvard College).

28 Cubberley (note 23), 79-80.

29 Ayers (note 22), 32.

30 See id.; Klise and Hough (note 17), 212. According to his obituary "Isaac Sams was born in England and was for years the most prominent figure in Educational circles in the county of Highland." "Isaac Sams," The News-Herald (Hillsboro) (March 4, 1897), 1.

31 Lobingier (note 8), 529. See also Klise and Hough (note 17), 468, and "Matters about Home," Highland County Weekly News (July 5, 1866), 3. Scott's valedictory is described as "[A] chaste and touching effort, gaining much by being simple and to the point." Scott himself is described 
University, two of its six professors taught Latin or Greek language and literature, and the university's own preparatory college's curriculum was that of the classical grammar school. ${ }^{32}$ The traditional, classics-based curriculum was required for admission by universities in the United States until later in the nineteenth century. ${ }^{33}$

After obtaining his A.B. degree, Scott stayed on at Miami University for another year to earn his A.M., and the following year, 1868, he was admitted to the Ohio bar. In July of that year he and a Hillsboro acquaintance set off for the West Coast by train. ${ }^{34}$ Unfortunately, there is scant evidence of Scott's experiences over the next several years. According to what is most likely self-reported information in a Miami University alumni catalog, Scott practiced law in Leavenworth, Kansas, from 18691870. ${ }^{35}$ A Hillsboro newspaper also indicates he was on the Floral Hall Committee for the Agricultural Society's county fair in 1869. ${ }^{36}$ There is no objective, documentary record of Samuel's activities from 1870 until 1874. The Miami University alumni catalog indicates he was practicing law in San Francisco from 18741875,37 and other probably self-reported information in a directory

in this way: "His head is ample - almost massive - in its proportions; and his deep-set gray eyes have an intangible something that flashes determination of character and rare power in repose ...." Id. (This newspaper and the other local newspapers cited in this article are available, for dates through 1922, in the Library of Congress's website Chronicling America: Historic American Newspapers.)

32 Fortieth Annual Circular of Miami University (Oxford, OH 1865), 3, 11-12. Samuel P. Scott is listed as being in the junior class of that year.

33 See R. L. Church and M. W. Sedlak, Education in the United States (New York 1976), 234, for a table showing when several institutions of higher education first accepted new subjects as a basis for admission. For example, the University of Michigan accepted modern U.S. history as a grounds for admission in 1869. In 1828, the Yale Report had lauded the mental discipline students obtain from studying the classics, saying it prepared them to think for themselves about other problems. The Report's admonition was to first exercise the mind, then furnish it, with Latin and mathematics being the best tools for exercise. Id., 31-32.

34 "Our young friends, Messrs. Samuel P. Scott and Carlisle Barrere, having finished their study of law, and been admitted to practice, started west on a prospecting tour last Monday .... They expect to visit the Terminus of the Pacific Railroad before they return." "Matters about Home," Highland County Weekly News (July 2, 1868), 3.

35 Alumni Catalog, Miami University 1809-1909 (Oxford, OH 1909), 115, available at The Internet Archive (website).

36 "Twentieth Annual Fair of the Highland County Agricultural

Society," The Highland Weekly News (Aug. 19, 1869), 1.

37 Alumni Catalog (note 35), 115. 
indicates he was in the practice of law from 1868-1875.38

Scott's life comes into focus a bit better from 1875, when he returned to Hillsboro to help run the family business as his father's health declined. ${ }^{39}$ For many years thereafter, local newspaper reports offer accounts of some of his activities as one of Hillsboro's high-profile citizens; e.g., a 1878 article lists him as Generalissimo of the Hillsboro chapter of the Knights Templar. ${ }^{40}$ Scott's first published article appeared in $1876,{ }^{41}$ and the first of his travel writings was published in $1881 .{ }^{42}$ Thus, it is tempting to speculate that he spent those undocumented years between 1869-1874 traveling abroad.

However, internal evidence in Scott's Through Spain indicates this cannot be so. In that book he refers to listening to Carlist soldiers on a train soon after "the recent amnesty," 43 and the second Carlist War ceased in 1876. ${ }^{44}$ Furthermore, Scott recounts witnessing a royal cavalcade by King Alfonso XII, ${ }^{45}$ who reigned from 1874-1885. ${ }^{46}$ Thus, unless he was using literary license to add interest to his story, Scott must have only started to learn the family business in 1875 , rather than to have taken it over completely, ${ }^{47}$ and must have traveled in Spain some time between 1875 and 1880. Considering these references, and given the interest of local newspapers in Scott Family activities, it is more probable that during the largely undocumented period of 1869-1874 Scott was practicing law in Kansas and California, or traveling in the West, than idling in Hillsboro.

38 The Ohio Bluebook: or Who's Who in the Buckeye State; A Cyclopedia of Biography of Men and Women of Ohio, ed. C. S. Van Tassel (Toledo, $\mathrm{OH}$ 1917), 326.

39 Lobingier (note 8), 529.

40 "Knights Templar," The Highland Weekly News (Oct. 10, 1878), 3.

41 S. P. Scott, "Algernon Sidney," Potter's American Monthly, 6 (1876), 333.

42 S. P. Scott, "Granada and the Alhambra," Lippincott's Magazine of Popular Literature and Science (new series), 1 (old series, 27) (1881), 425.

43 Scott (note 4), 22.

44 "Carlist," The Columbia Encyclopedia, 5th ed. (New York 1993), 458. The first Carlist war ended in 1840. Id.

45 Scott (note 4), 39-40.

46 "Alfonso XII," The Columbia Encyclopedia, 5th ed. (New York 1993), 63.

47 This conjecture is supported by advertisements in the local paper showing William Scott as still being on the board of directors of the Citizens' National Bank in 1882. See, for example, The Highland Weekly News (Jan. 26,1882), 1. 


\section{Civic leader}

In any case, we can be reasonably sure that by 1875 Scott resided primarily in Hillsboro and was taking on the role of understudy for his father, not only in business, but also as a leading member of the community. The county newspaper, in addition to describing him as a leader of the local Knights Templar in 1878, also lists him as heading a delegation of Masons to a meeting in Cincinnati in $1882 .{ }^{48}$ By the time his father, William, died in $1886,{ }^{49} \mathrm{~S}$. P. Scott seems to have been prepared to become head of the prominent Scott Family of Hillsboro.

In 1888, S. P. Scott, following in William's civic footsteps, was appointed to the Library Board, ${ }^{50}$ and in 1890 he was elected to the Hillsboro city council. ${ }^{51}$ A newspaper article of 1892 reported that he was the single largest shareholder in Hillsboro's three national banks. ${ }^{52}$ Two years later, an advertisement listed him as president of the Hillsboro Fair, the town's major social event. ${ }^{53}$ Also in 1894, the Hillsboro newspaper congratulated Scott and the First National Bank on his having been named "acting" president (as opposed to nominal president, which he had been previously), writing that " $[\mathrm{t}]$ his change brings into the business his splendid business talents."54 In 1895, he was listed as treasurer of the Equitable Building and Loan Association as well. ${ }^{55}$ That same year, at the age of 49 , Scott further solidified his position in local society by marrying Elizabeth Woodbridge Smart, who belonged to a prominent family in the nearby town of Chillicothe. ${ }^{56}$ At this

48 E.g., S. P. Scott is reported to have represented the Hillsboro Masons at a Masons meeting in Cincinnati in 1882. The Highland Weekly News (March 2, 1882), 5.

49 William Scott died Jan. 7, 1886. "Highland County Bar," The Highland Weekly News (Jan. 13, 1886), 5.

50 "Uncommon Council," The News-Herald (Hillsboro) (May 5, 1886), 5.

51 He is described as being "newly elected" in May of 1890 . "Council's Doings," The News-Herald (Hillsboro) (May 8, 1890), 5.

52 "They Hold Stock," The News-Herald (Hillsboro) (July 7, 1892), 5.

53 The News-Herald (Hillsboro) (August 9, 1894), 4.

54 “A Good Move," The News-Herald (Hillsboro) (July 26, 1894), 5.

55 The News-Herald (Hillsboro) (March 21, 1895), 5.

56 See Klise and Hough (note 17), 468. The local newspaper account indicates the bride is from Rapid Forge, Ohio and that the couple "left at once for the East, where they will enjoy an extended wedding trip." The News-Herald (Hillsboro) (Oct. 17, 1895), 3. (Rapid Forge no longer exists; it appears to have been a small town in Ross County, Ohio. See A Standard History of Ross County, Ohio . . . , 2, ed. L. S. Evans (Chicago 1917), 387.) A local history appears to have relied on oral history and weak memories when it gives the bride's name only as "Elizabeth Woodbridge" and states that after the wedding "They traveled extensively throughout 
point, Scott seems to have been well along on his deceased father's path, becoming a highly respectable married man, one of Hillsboro's leaders in commerce and civic activity. How, and why, did he change course to become a solitary gentleman-scholar, which he appears to have done around 1896 ?

\section{Reputation lost}

Lacking his correspondence, a journal, or other self-reflection, we only can look at local newspaper reports and at what Scott was working on at the time, and conjecture about his transition from civic-minded businessman to reclusive scholar. The most plausible speculation is that Scott's withdrawal from a high-profile life in Hillsboro society was triggered primarily by the fallout from his bank's liquidation. In July of 1896, the First National Bank, of which he had become hands-on president in 1894, as noted above, closed its doors and was turned over for voluntary liquidation to the United States Comptroller of the Currency. According to a newspaper account, "[i]t was generally understood that the bank had been seriously affected about the time of the failure of the Citizens' National Bank"57 (another bank in which Scott was a major shareholder). ${ }^{58}$ A statement issued by Scott and three other board members said: "This course [liquidation] has been unnecessarily precipitated by the threatened action of the two stockholders, who refused to pay their assessments ordered by the Comptroller of the Currency ...." "59 This statement further maintained that the directors believed the bank was "perfectly solvent, and if the assets be carefully and judiciously administered, the creditors will be paid in full."60 However, in subsequent litigation, Scott was found to be guilty of malfeasance in his position of president of the First National Bank and to be liable to shareholders and creditors for $\$ 18,000 .{ }^{61}$

Europe, where he acquired the knowledge of several languages." Ayers (note 19), 206-207.

57 “The First National," The News-Herald (Hillsboro) (July 23, 1896), 1.

58 It is not clear whether he still held Citizens' National Bank shares at this time, but he had been a major shareholder four years previously as noted in "They Hold Stock" (note 52).

59 "The First National" (note 57).

60 Id. An article in a Cincinnati paper, which reads rather like a press release from the bank, claims that "depositors of the Hillsboro First are resting easy about their money." "No Stir," Cincinnati Enquirer (July 19, 1896), 4. It goes on to say that when the bank went into suspension, it had on its books about $\$ 150,000$ over its deposits, with a stock liability of $\$ 100,000$, of which about $\$ 80,000$ was assessable. Id.

61 "Liable for $\$ 18,000$," The News-Herald (Hillsboro) (July 13, 1905). 
This finding of malfeasance must have been greatly embarrassing to Scott, especially because the special master who made the determination was General B. R. Cowen. ${ }^{62}$ Benjamin Rush Cowen (1831-1908) was by this time one of Ohio's luminaries "a prominent actor in the affairs of his [Republican] party, his state and the United States, and whose public services entitle him to rank among the patriotic and distinguished men to have given fame to Ohio."63 For over two decades at the end of his career, Cowen was Clerk of the United States Circuit and District courts for the Southern District of Ohio. According to his biographer, General Cowen "was frequently appointed by the presiding Judge of the Circuit Court as referee or master in important cases in which it was necessary to unravel intricate conditions of fact, to settle complicated accounts and to make clear and correct findings." 64 That Cowen was appointed to this case would have underlined its importance to all involved and would have made his conclusions all the more humiliating for Scott.

The newspaper account of Special Master Cowen's findings can be summarized as follows: 1) Cashier L. P. Smith drew $\$ 5,257$ for himself from an estate account he was administering, and Scott, as well as S. H. Richards, a bank director, knew Smith was misapplying the money; 2) Scott "received the benefit of the deal, and the General ruled he should be accountable financially"; 3) Scott and Richards were responsible for the bank's loss of $\$ 5,000$ since they accepted "worthless" securities for a $\$ 10,000$ loan, but Scott was the financially liable party because he endorsed the paper; 4) when Scott was told that, due to the closing of another bank [Citizens' National], he should expect a run on his, he put up bonds to acquire cash, but they were put into a special account in his name, not the bank's; and 5) the "affair was enveloped in complicated entries and accounts" the result of which was that Cowen found both Scott and Richards guilty of malfeasance and liable for $\$ 18,000$. However, Cowen focused on Scott, and held him personally liable, because he was the only solvent bank official, "and it is from him that the creditors will try to recover the money adjudged to be their due."65

Other newspaper reports add some detail. First National

$62 \mathrm{Id}$.

63 W. H. Mackey, "Benjamin Rush Cowen," Ohio History, 18 (1909), 149, available at Ohio History Journal Archive (website).

64 Id., 154.

65 "Liable for $\$ 18,000 "$ (note 61), 1. All the information and quotations in this paragraph are derived from this source, which refers to the Cincinnati Tribune (July 12, 1905). 
Bank Head Cashier, Lynne Starling (L. S.) Smith and bookkeeper Joseph A. (J. A.) Head were arrested in connection with alleged wrongdoing in the bank. ${ }^{6}$ Head, who had been a successful businessman in Hillsboro, was indicted by a federal grand jury in Cincinnati for making false statements in his report to the Comptroller of the Currency. ${ }^{67}$ The charges against Smith are not clear, but a later court decision refers to his "rascally manipulations."68 However, there is no indication either Smith or Head ultimately was tried for his activities. ${ }^{69}$

Of course, it was not only Cowen's 1905 decision that would have vexed Scott; the case, and other litigation surrounding the bank liquidation, went on for years. A newspaper article of February 4, 1897 reported on a suit by Scott and other First National Bank shareholders who had paid the bank's voluntary assessment of fifty percent (which included Scott's sister and mother) against shareholders who had refused to pay the assessment. ${ }^{70}$ (Kirby Smith, one of those shareholders, and a dissenting First National Board member, later brought an appeal against that judgment in the federal Circuit Court in Cincinnati. ${ }^{71}$ ) The next month, the same newspaper carried a short piece indicating that a bank inspector from Washington, D. C. was in town at the request of dissident shareholders who wanted the Comptroller to sue Scott and Smith for mismanaging the bank, "with a view to establishing grounds for a civil suit."72 (The same issue of the newspaper also contains a front page letter from bank director J. H. Richards in which he refers to the many articles published, and rumors circulated, "making grave and libelous charges," including his "having been engaged in speculations with Mr. S. P. Scott or Mr. L. S. Smith, by which large sums of money were lost."73) A civil suit against Scott and Richards began in September of 1900, when a referee started taking testimony in an action brought by

66 "Suspense Among Hillsboro Folks," The Cincinnati Enquirer (Feb. $25,1897), 5$.

67 Id.

68 "United States Court," The Cincinnati Enquirer (April 11, 1906), 7.

69 The same newspapers that carried the information noted did not carry later stories about the case. It is possible, though, that Smith died before a trial could commence. An April 1899 report on Smith's death refers to his "adversity" but makes no mention of litigation per se. "Lynne Starling Smith," The News-Herald (Hillsboro) (April 13, 1899), 1.

70 The News-Herald (Hillsboro) (February 4, 1897), 1.

71 "Federal Building," The Cincinnati Enquirer (June 24, 1899), 5.

72 The News-Herald (Hillsboro) (March 4, 1897), 5.

73 "A Card," The News-Herald (Hillsboro) (March 4, 1897), 1. 
shareholders C. E. Bell, Kirby Smith, and H. M. Brown. ${ }^{74}$ Four years later, Scott won a small judgment against two estate administrators in a "suit over the settlement of the old First National Bank business."75 Meanwhile, the bank's receiver was winding up the business, which involved further publicity for Scott, such as that regarding the sale of bank-owned lands to Scott, his sister and mother, in exchange for the cancellation of certain of their claims on the bank. ${ }^{76}$ And in 1905, other litigation related to First National was argued before the federal appellate court in Cincinnati. ${ }^{77}$

In short, it seems fair to say that the liquidation of the First National Bank and the ensuing litigation and recriminations must have been traumatic for Scott and the entire town of Hillsboro. Scott went from being the town's leading banker, praised for his splendid business talents, to being found guilty of malfeasance by a grand personage of Ohio and being referred to by a federal judge as "a man much below first-rate business qualifications . . e easily deceived and misled."78 From the time of the bank liquidation, Scott ceased to be noted in the local newspapers as carrying out the sort of civic tasks he used to engage in. Except for one brief piece indicating he had been elected president of the Highland County Fair, ${ }^{79}$ the only mentions of S. P. Scott after the bank liquidation until his death are such items as squibs indicating he and his wife had gone to "northern health resorts," 80 that he was seeking the return of his horse, ${ }^{81}$ and that his dog been killed. ${ }^{82}$

Other evidence certainly suggests that S. P. Scott was not well liked in Hillsboro by the time he died. A local history claims that "An insight into the character of Samuel P. Scott is best

74 "First National Bank Suit," The News-Herald (Hillsboro) (September 20,1900). A later article notes that by December the case had generated 2,678 pages of testimony. "Large Fees," The News-Herald (Hillsboro) (December 6, 1900), 1.

75 "Common Pleas Court," The News-Herald (Hillsboro) (Feb. 25, 1904), 1.

76 "Legal Notice," The News-Herald (Hillsboro) (April 7, 1898), 6.

77 "Bankers Will be Interested in Case Pending in Federal Appellate Court," The Cincinnati Enquirer (April 14, 1905), 5.

78 "United States Court" (note 68). However, the judge went on to opine that "it would have required a man of considerable [sic] more ability to have kept up with the rascally manipulations of Cashier Smith at any time or to any considerable extent." Id.

79 The News-Herald (Hillsboro) (July 5, 1900), 5.

80 The News-Herald (Hillsboro) (August 4, 1898), 5.

81 The News-Herald (Hillsboro) (August 17, 1899), 5.

82 "Council Meeting," The News-Herald (Hillsboro) (Aug. 9, 1900), 1. 
summed up in a statement made by a contemporary lawyer: 'He is eccentric, very overbearing and not well liked." 83 The cemetery monument to Samuel and Elizabeth Scott is telling. Of Elizabeth Woodbridge Scott it says: "Loved, Admired, Most Highly Respected by All Who Knew Her"; regarding Samuel P. Scott it merely states: "1846-1929." 84

It should also be remarked, however, that it is also quite possible Scott, who turned 59 in the year Cowen issued his decision, had long tired of business and social activities and had wanted to devote more time to writing before the bank calamity. In the preface to his History of the Moorish Empire in Europe, which is dated 1903, Scott says that the work "engaged the attention of the author for more than twenty years." 85 In fact, one has to wonder whether Scott's dedication to the History might have caused him to be inattentive to his bank duties and might have contributed to his downfall. ${ }^{86}$ The book's long-anticipated appearance also may have provided him a much needed boost during his difficult years of bank litigation, and it might have made it easier for him to cease his previous civic activities and focus instead on scholarly endeavors. Whatever the reason, it definitely is at this time shortly after the History was published, and following the bank litigation - that Scott withdrew from Hillsboro society and became a reclusive writer.

\section{Scott's writing career}

\section{A. First publication}

Being named class valedictorian and earning his Phi Beta Kappa membership are evidence of Scott's early intellectual inclinations. ${ }^{87}$ However, as noted earlier, his first published scholarship did not appear until 1876, when he was about 30 . This piece, about Algernon Sidney (1623-1683), English Republican politician and member of the Long Parliament, appeared in Potter's

83 Ayers (note 19), 206. It should be kept in mind, however, that this is the same source that incorrectly reported the name of his bride and on their travels. See note 56.

84 Photograph of the monument on file with the author.

85 History (note 5), v. He wrote on the handwritten manuscript of his last chapter of History: "finished Jan. 13, 1902."

86 The preface also indicates that he wrote most of History before 1898. Id., vii. It should be noted that his beloved mother, Elizabeth Jane, died in 1908; this probably reinforced his later isolation. "In Memory of Mrs. Elizabeth J. Scott," The News-Herald (Hillsboro) (Nov. 5, 1908), 1.

87 Lobingier (note 8), 529. See also Klise and Hough (note 17), 468. 
American Monthly. ${ }^{88}$ The subtitle of the magazine - "History, Literature, Science and Art" - hints at its character as a wideranging, intellectually oriented journal for well-educated persons, rather than a footnoted scholarly review for specialists.

B. Travel writings about Spain

Scott's series of articles about Spain and his experiences there appeared from 1881-1883. These high-minded historical and culturally oriented pieces were published in Potter's American Monthly, Lippincott's (a similar journal subtitled "A Magazine of Popular Literature and Science"), and The Continent. ${ }^{89}$ Scott focused for the next few years on shaping his experiences and thoughts on Spain into his first book, Through Spain: A Narrative of Travel and Adventure in the Peninsula, which was published three years after the last of his travel articles. ${ }^{90}$ This work, fulsomely dedicated to his mother, ${ }^{91}$ was positively reviewed and may have encouraged him in his intellectual pursuits. ${ }^{92}$

C. History writing

Scott's next book, the three-volume History of the Moorish Empire in Europe, was not published until 1904. Scott's assertion, noted above, that he worked on it for over twenty years is verified to a significant extent by the handwritten manuscript of History that resides in the Thomas Jefferson University archives. At the top of chapter I, Scott wrote "Begun April 2, 1889,"93 and, of course, he

88 Scott (note 41$)$.

89 See Appendix 1 for a list of these and Scott's other writings.

90 Scott (note 4). In his preface, Scott explained that the articles had been "intended to illustrate the civilization and influence of the Moors in Spain," so that he had to revise them extensively for the book. Id., 7.

91 "To my mother, the careful guardian of my childhood, the kind assistant of my youth, and the beloved companion of my maturer years, this volume, the first fruit of my literary labors, is affectionately dedicated." Id., 6 .

92 "Two Books on Spain," The Spectator (Aug. 21, 1886), 21; Book Notes, 3 (1885-1886), 92; Overland Monthly \& Out West Magazine (2nd ser.), 7 (1886), 335; The Guardian (March 3, 1886), 16 (advertisement quoting Galignani's Messenger). The latter says of Scott's writing: “The panorama of Spanish cities, landscapes, human life, and history is unrolled before the reader in such a way that his interest never flags." Id.

93 Manuscript on file with the Thomas Jefferson University Archives, MS 051. (Photocopy of this page on file with the author.) On the same page is the note: "This chapter, written three times, was finally completed Jan. 30, 1901. It is still unsatisfactory even after careful and repeated revision." Id. Another handwritten manuscript page states: "The title of this work is to be History of the Moorish Empire in Europe, and its 
would have to have started his research on it years before. The reviews of this work were more mixed than that of his first book.

Two rather lengthy reviews by respectable publications aimed at an educated readership were quite positive, both of them noting Scott's extensive research and readable literary style. The New York Times declared of History: "In these volumes the learning of the late R. Dozy of Al-Makkari, Romey, Rosseuw St. Hilaire, le Bon, Sédillot, Casiri, and the lore of the original Arabic and Spanish chronicles have been conjured with in a style to evoke, Aladdin-Like, the vision of the genius of Islam." 94 And The Spectator referred to Scott as a worthy disciple of Gibbon, saying that "Nowadays it is quite refreshing to find an author who still has the courage to plan, and the industry to carry out, such an imposing work." 95

However, the two scholarly reviews of History were decidedly negative. Both of these pointed to what the reviewers perceived as a lack of discernment by Scott in his use of the many sources he claimed to have read and his failure to support his statements with specific references. One opined of Scott that "Whenever he finds an attractive statement, no matter what the source, he puts it down, and the material thus collected has been so carelessly worked over that contradictions are frequent, and the point of view is sometimes changes two or three times in as many pages." 96 The other review pointed out that Scott was "not willing to tell us in a single footnote the source of any specific statement." 97 These academic reviewers also cast doubt on the accuracy of many of Scott's assertions.

Influences on Modern Civilization." Manuscript on file with the Thomas Jefferson University Archives, MS 051. (Photocopy of this page on file with the author.) The archival description of the Samuel Parsons Scott Papers is available at University Archives and Special Collections, Thomas Jefferson University (website).

94 "The Moorish Empire," N.Y. Times (Sept. 10, 1904), $22 . \quad$ Scott writes glowingly about the Moors: "[The book's] object is an attempt to depict the civilization of that great race whose achievements in science, literature, and the arts have been the inspiration of the marvelous progress of the present age." Scott (note 5), v.

95 "History of the Moorish Empire in Europe," The Spectator (Nov. 5, 1904), 13.

96 A. C. Howland, "History of the Moorish Empire in Europe," Annals Am. Acad. of Pol. \& Soc. Sci., 1 (1905), 152-53.

97 F. W. Williams, "History of the Moorish Empire in Europe," American Hist. Rev., 10 (1905), 372, 373. 


\section{Scott's library}

This is a convenient place to divert briefly to the topic of Scott's library, a subject to which we will return later. One of the critical reviews quoted above points out that Scott lists 717 sources in fifteen languages, and the reader cannot help but sense that the reviewer doubts the author has read them all. ${ }^{98}$ A review of Scott's library does not settle the matter, but it sheds some light on it. First of all, Scott's private library was very large. It consisted of over 4,200 titles and 8,000 volumes in many languages and on diverse subjects, but mostly on history, primarily ancient and medieval, and on law. ${ }^{99}$ By way of comparison, it is worth noting that Justice Blume's library contained about 2,350 volumes, many of which were in German, and 860 of which were on Roman law and history. A local history describes Scott's library as "one of the finest private libraries in Ohio," and says "It contained many rarities and filled an entire floor of his office building." 100

The inventory made of Scott's property for the Highland County Circuit Court's Probate Division is only modestly helpful in ascertaining the character of his library. While the inventory does systematically account for both the library in his house and the one in his office, sometimes listing specific titles and estimating values, e.g. "Set Michelet History of France, 19 vol. — \$19," it also often contains entries such as: "51 books" (without giving titles) or "1 set Burke" (without specifying the number of volumes). ${ }^{101}$

Much more helpful in assessing Scott's library is the card catalog created for it by Thomas Jefferson University after its receipt by them as part of his bequest. Scott left most of his

98 "But at this point suspicions are aroused, for it would be difficult for one not already master of the field to find his way intelligently among the 717 separate works in 15 languages that are here thrown together." Howland (note 96), 152.

99 These figures and the descriptions that follow are based on the author's analysis of the inventory list in the probate court records, and catalog cards made of the collection when it was transferred to the Thomas Jefferson University after Scott's death. Photocopies of the catalog cards are on file with the author. See also Angelo (note 11), as well as notes 101-102 below and accompanying text.

100 Ayers (note 19), 207.

101 Inventory Record, Book 35 at 51, Highland County Probate Court. It is interesting to note that one of the court-appointed appraisers was J. A. Head, who had been arrested in conjunction with the failure of Scott's First National Bank. Id., 47. Regarding Head's arrest, see note 66 and accompanying text. This approval by the Probate Court of Head as one of the appraisers suggests he was cleared of wrongdoing in the bank affair. 
estate, including his extensive library, to this Philadelphia university to establish a library there, because he believed a member of the university's faculty he met on a train cured him of hay fever. ${ }^{102}$ (Interestingly, a newspaper notice in 1895 states that Scott had returned from a stay of two weeks in Philadelphia, and Scott wrote prefaces to books there in 1903 and 1908.103) Of the substantial percentage of the titles in Scott's library that were in foreign languages, most were in Romance languages, mainly Spanish and French; relatively few were in German, Latin, Greek, Arabic, and a very few were in Scandinavian. The collection likewise contained many foreign language dictionaries, glossaries, grammars, etc. Although Scott was a very wealthy man, it is hard to imagine he would buy, and house, so many books in foreign languages if he could not make any sense of them and if he did not intend to use most of them. Clearly he was enamored of foreign languages, and seems to have had a gift for them.

With respect to the materials Scott used in writing History, to each chapter of his handwritten manuscript he appended sheets labeled "Books Read \& Noted." He appears to have used these later as the basis for the single, lengthy handwritten list entitled "Authorities Consulted in the Preparation of this Work."104 This latter list appears under the same title in the printed version of History and is the one referred to with some incredulity by the reviewer noted above. The "Authorities Consulted" list is longer than the sum of the individual chapter "Books Read and Noted"

102 Angelo (note 11). See also E. T. Cunning, "History of Jefferson Medical College Library, 1898-1953," 18 (unpublished manuscript) (on file with the Thomas Jefferson University Archives, MS 051). Cunning gives the amount bequeathed as $\$ 1,250,000$, which probably stems from a newspaper article in the TJU Archives stating that amount. "Hay Fever Patient Wills $\$ 1,250,000$ to Jefferson" (unattributed photocopy of newspaper article) (on file with Thomas Jefferson University Archives, MS 051). Angelo states that figure as the total value of the estate, which was the initial estimate given in Hillsboro newspaper articles. See note 153 and accompanying text. The will itself stated: "I do give ... the rest and residue of my estate, real and personal to the Board of Trustees of Jefferson Medical College to be used for the foundation and maintenance of a library .... I make this bequest in grateful acknowledgment of the inestimable service rendered me by one of the Professors of said Institution, in relieving me of hay-fever, thereby prolonging my life in comparative comfort for many years." "Item 2," Samuel P. Scott Will (note 15). Ultimately, the Scott estate was valued at $\$ 1,014,128$, and the Jefferson Medical College received $\$ 754,128$. See notes $153-165$ and accompanying text.

103 The News-Herald (Hillsboro) (May 16, 1895), 5. See History (note 5), vol. 1, vii, and The Visigothic Code (note 2), xliv, respectively. ${ }^{104}$ On file with the Thomas Jefferson University Archives, MS 051. 
lists, probably because it includes works merely consulted, in addition to those actually noted. On the whole, it seems to me plausible that Scott did read at least parts of all of the books claimed in the "Authorities Consulted" list.

Unfortunately, Scott's library has not remained intact. Thomas Jefferson University started as Jefferson Medical College and has remained exclusively a health sciences university. Therefore, it had little practical use for Mr. Scott's library. Thomas Jefferson University Board of Trustees minutes of 1940 recount that the Dean read to the Board the portion of Scott's will that empowers the Board to sell the books, noted there were "many valuable non-medical books," and asked the board if they could be sold, with the proceeds going to the Scott fund. ${ }^{105}$ Around 1950, the vast bulk of Scott's library was sold to the Samuel H. Kress Foundation, which then apparently gave most of the contents to Bucknell University. ${ }^{106}$ However, many of the books recorded as having been sold from Scott's collection to the Kress Foundation were not listed in the Bucknell catalog when I visited in 2013.107 Those of Scott's books at Bucknell that I examined did not contain annotations or other indications of how he may have used them in his work. (It is perhaps worth noting,

105 Board of Trustee Minutes, Thomas Jefferson University (unpublished manuscript) (on file with the Thomas Jefferson University Archives, MS 051). The provisions reads: "[S]aid Board of Trustees are hereby empowered to sell, to the best advantage, such of the property of my Estate as may come into their hands, which it may seem advisable to them to dispose of for that purpose [i.e., the foundation and maintenance of a library]." Id.

106 "Admiral Kauffman reported the sale ... of the books in the library received from the Scott Estate in the amount of $\$ 3,500 \ldots$. . Board of Trustee Minutes, Thomas Jefferson University, May 27, 1950 (unpublished manuscript) (on file with Thomas Jefferson University Archives, MS 051). The catalog cards made by TJU of Scott's collection consist of four boxes labeled "U.A. [University Archives] Card Catalogue. S.P. Scott Books Sold to Kress Foundation for Bucknell University.” Rush H. Kress was a long-time president of the Samuel H. Kress Foundation. He graduated from Bucknell in 1900 and was a trustee and benefactor of the university. "Strong Leadership Enrolled for Campaign," The Bucknell Alumnus (Jan. 1959), 14. There is a Rush H. Kress residence hall at Bucknell.

${ }^{107}$ Interestingly, the cards in Bucknell's Special Collections Library and Archives for books from Scott's library that indicate they were gifts from Rush H. Kress bear acquisition dates from May 1, 1951 - Nov. 1, 1971. This may indicate that the Foundation passed Scott's books to Bucknell selectively over a long period, or it may indicate a lengthy processing period at Bucknell. Some of Scott's books contain a bookplate showing a shield beneath which, on a ribbon, is the phrase Famam Extendimus Factis, and below which is written "S. P. Scott." 
by comparison, that Justice Blume heavily annotated the books he used for his translations.)

E. Translations

\section{The Visigothic Code}

We do not know whether Scott read any of the reviews of History of the Moorish Empire in Europe. In any event, he most likely already was at work on his translation of Visigothic laws by the time the reviews of History appeared in 1904-1905, given that the preface to The Visigothic Code is dated 1908.108 It seems probable that Scott's interest in this ancient legislation was piqued by his previous research on the history of Spain and of the Moors in Europe. (At the time of his death, he also was underway with a work entitled History of France. ${ }^{109}$ ) Scott's The Visigothic Code was the first of what would be several translations he made of foreign laws, most of them ancient compilations. As was noted in one of the subsequent reviews of the book, the Visigothic Code incorporated parts of the Roman-law influenced Breviary of Alaric and the West Gothic Code of Euric, and probably had some of its religious flavor imparted to it by the Council of Toledo. ${ }^{110}$ Scott undoubtedly encountered all of this information in his research on the history of Spain and on the Moors.

Scott was generally immersed in Spanish law when The Visigothic Code was published, for in 1907 he was appointed one of the original editors of the American Bar Association's newly created Comparative Law Bureau, with special responsibility for Spain. ${ }^{111}$ (The appointment suggests Scott was not as isolated as it might appear at first glance, but I have not been able to find any correspondence, or other evidence, of his professional relationships.) One of the objects of the Comparative Law Bureau was "the translation into English and publication of foreign fun-

108 Scott (note 2), xliv.

${ }^{109}$ In the codicil to his will, Scott orders: "I direct my Executor to employ such part of my estate as may be necessary for the publication of any manuscripts which may remain unpublished at my death: viz: Those that are in the hands of the Secretary of the Comparative Law Bureau ... My translation of the Civil Law ... my unfinished History of France." Samuel P. Scott Codicil (Nov. 2, 1926), § 2 (unpublished manuscript) (digital image on file with author).

110 "The Visigothic Code," Am. L. Rev., 45 (1911), 478 (book review). The reviewer points out that it was King Receswinth (652-672) who formally issued the compilation, which is also known as the Forum Judicum. Id., 479.

111 "Report of the Board of Managers of the Comparative Law Bureau," Ann. Report A.B.A., 33 (1908), 619, 620. 
damental laws"; ${ }^{112}$ hence, it is not surprising that the Bureau published The Visigothic Code in 1910 as the first in its translation series. Scott dedicated The Visigothic Code to his fellow members of the Bureau, ${ }^{113}$ again, perhaps suggesting he was not as solitary a scholar as it might otherwise seem. Certainly Scott was an active Bureau member, writing pieces about Spanish legal bibliography, as well as articles on substantive Spanish law topics, for the Bureau's Annual Bulletin ${ }^{114}$ until it ceased in 1914. Thereafter, he provided purely bibliographic notes for the "Contributions of the Bureau of Comparative Law of the American Bar Association" section in the ABA Journal until 1927. ${ }^{115}$

One hopes Scott's active involvement with the Bureau helped him deal with the sharply critical reviews of The Visigothic Code. Lacking his correspondence, we cannot know whether he even was aware of the critical reception, but when so highly regarded a scholar as Paul Vinogradoff savages one's work as "material for the solution of the problem why people who have nothing to do with scholarship and research undertake tasks of learning,"116 and goes on to make further damning remarks, we suspect the author knew of the critique.

112 “Objects," Ann. Bul. Comp. L. Bureau A.B.A., 1 (1908), 2.

113 "To my fellow members of the Comparative Law Bureau, in the hope that it may prove an acceptable contribution to the literature of the noble science of the law, this translation of one of the most venerable monuments of jurisprudence is dedicated." Scott (note 2), iii. It should be pointed out that several members of the Bureau were well-known academics. In 1915 these included, as managers, John Wigmore and Roscoe Pound (the latter of whom also was an editorial staff member for general comparative law) as well as Samuel Williston, an editorial staff member for Germany. A.B.A. J., 1 (1915), 591.

114 S. P. Scott, "Spanish Jurisprudence Judicially Considered," Ann. Bul. Comp. L. Bureau A.B.A., 2 (1909), 14, and S. P. Scott, "Spanish Criminal Law Compared with that Branch of Anglo-Saxon Jurisprudence," Ann. Bul. Comp. L. Bureau A.B.A., 3 (1910) 62.

115 Only initials were given for the bibliographic contributions of $\mathrm{Bu}-$ reau members in the $A B A$ Journal. See, for example, "S.P.S." following "European Legislation and Decisions," Spain, A.B.A. J., 13 (1927), 230, 231 (within the "Contributions of the Bureau ..." section starting at 204) (1927). Scott's last listing as a member of the Bureau's editorial staff was in this same issue. See "Organization of Work and Bureau," A.B.A. J., 13 (1927), 204. Compare "Organization and Work of Bureau," A.B.A. J., 14 (1928), 210.

116 P. Vinogradoff, “The Visigothic Code,” Law Q. Rev., 27 (1911), 373. Among other criticisms, Vinogradoff asserted Scott was "evidently innocent of any acquaintance with the standard edition of Visigothic laws," that "he does not even know of the existence of the Paris fragments of Euric's law," and that "he knows nothing about the curious affinities between Gothic and Scandinavian legal customs discovered by Ficker.” Id. 
Scott can be said to come out ahead on the final tally of reviews in terms of simple numbers. My subjective scorecard for them is: positive $-4 ;{ }^{117}$ mixed $-3 ;{ }^{118}$ negative $-3 .{ }^{119}$ However, the reasonably well-informed reader cannot help but conclude that the negatives have the better part of the argument. The latter tend to be more specific in their criticisms than the positive reviews are in their praise. The critics note, for instance, the many misstatements in Scott's preface (e.g. his belief that Euric's law was wholly lost) $)^{120}$ and point out that he apparently was unaware of Zeumer's standard Latin edition of the code. ${ }^{121}$ The friendlier reviews refer more generally to his prose style ${ }^{122}$ and the difficulty of the Latin being translated. ${ }^{123}$ The mixed reviews tend to do both, criticizing Scott's scholarship, ${ }^{124}$ but noting the

117 [M.S.], "The Visigothic Code," Law Mag. \& Rev. Quart. Rev. Juris. (5th ser.), 36 (1910-1911), 341; J. Macintosh, "The Visigothic Code," Jurid. Rev., 23 (1910-1922), 300 (hereafter Juridical Review Visigothic Code); [G.F.D.], "The Visigothic Code," Penn. L. Rev., 50 (1910), 200; [W.W.S.], "The Visigothic Code," Ann. Bul. Comp. L. Bureau A.B.A., 3 (1910), 222 (hereafter Annual Bulletin Visigothic Code).

118 [J.H.D.], "The Visigothic Code," Mich. L. Rev., 9 (1910), 172 (hereafter Michigan Law Review Visigothic Code); "Laws of the Visigoths," Green Bag, 23 (1911), 583 (hereafter Green Bag Visigothic Code); [E.A.J.], "The Visigothic Code," Yale L.J., 20 (1910-1911), 424.

119 Vinogradoff (note 116); "The Visigothic Code," Am. L. Rev., 45 (1911), 478; M. Smith, "The Visigothic Code," Colum. L. Rev., 11 (1911), 695 (hereafter Columbia Law Review Visigothic Code). Only the initials M.S. are given after the last noted review, but a later publication indicates the author's name. See D. E. Grant, "Las Siete Partidas," Colum. L. Rev., 32 (1932), 780.

${ }^{120}$ Vinogradoff (note 116); Columbia Law Review Visigothic Code (note 119), 695.

121 Vinogradoff (note 116); Columbia Law Review Visigothic Code (note 119), 696.

122 Juridical Review Visigothic Code (note 117), 301 ("His English version is clear and fluent ....”); Annual Bulletin Visigothic Code (note 117), 222 ("The Translator's Preface is a refreshing surprise, because rarely is such delightful English found in a law book.").

${ }^{123}$ Law Magazine Visigothic Code (note 117), 341 ("A great debt is due to Mr. Scott for the trouble he has taken in translating, from the curious dog Latin ....”); Annual Bulletin Visigothic Code (note 117), 222 ("It is a matter of congratulation that the task of translation was undertaken by one ... capable of interpreting the vulgar tongue that developed in the Roman provinces....”).

${ }_{124}$ Green Bag Visigothic Code (note 118), 583 ("The document now translated by Mr. Scott is Erwig's revision of the Forum Judicum, although he assumes that he is translating the compilation of Chindaswind and Recceswind."); Michigan Law Visigothic Code (note 118), 174 ("The many notes ... sprinkled through the text could be made more helpful if the authorities for the statements of facts were given in each instance."). 
difficulty of the task and virtue of Scott's style. ${ }^{125}$

\section{Las Siete Partidas}

Scott probably was working on other translations even before The Visigothic Code was published in 1910. Although Las Siete Partidas was not published until 1931, the Comparative Law Bureau indicated in 1913 that the work had been translated by Scott and "was now ready for the printer."126 (More of its publication story is provided below.) It also should be noted in this context that Scott apparently had begun to train a secretary in 1911 and that he employed her in 1913. According to a later newspaper account, this secretary, a Miss Rhoades, claimed that "in $1911 \mathrm{Mr}$. Scott asked her to become his private secretary; that to prepare for those duties she studied under his direction for two years without pay; that her studies consisted of Latin and Spanish, along with a course in stenography and typewriting." 127 She further stated that she had gone to work for him in 1913 and had served as his secretary for 16 years. ${ }^{128}$ Thus, Scott appears to have been working in earnest on his translations in this period.

Certainly the Siete Partidas was a logical compilation for Scott to translate. It not only played an important role in the life of Spain, whose history so interested him, but it had had an impact in the Americas as well, including the United States. Finished in 1263, at the behest of Alfonso X, it officially became the law of Spain in 1505 and was applied to Spain's possessions in 1535. ${ }^{129}$ Owing to its use in the Americas, the impact of the Partidas in parts of the United States has been considerable. ${ }^{130}$

${ }_{125}$ Green Bag Visigothic Code (note 118), 584 ("The translation, however, seems to have been executed with pains and discernment in the face of considerable difficulties."); Michigan Law Review Visigothic Code (note 118), 173 ("The body of the text, too, is turned into clear and idiomatic English, an achievement which certainly involved no small amount of painstaking labor, if one considers the barbarous Latin of the original ....").

126 "Foreign Laws Now Accessible in English," Ann. Bul. Comp. L. Bureau A.B.A., 6 (1913), 9, 10. The previous year's report to the A.B.A. had indicated he was still working it. "Report of the Comparative Law Bureau of the American Bar Association," Ann. Rep. A.B.A., 35 (1912), 555.

127 "Suit for Third of Scott Estate," The News-Herald (Hillsboro) (Oct. 31, 1929), 1.

128 Id. See also notes $156-165$ and accompanying text.

${ }^{129}$ See generally R. I. Burns, "The Partidas: Introduction," Las Siete Partidas, 1 (Philadelphia 2001), xi.

${ }^{130}$ Id., xix-xxix (Burns). See also C. S. Lobingier, "Las Siete Partidas in Full English Dress," A.B.A. J., 15 (1929), 365. This article is of particular interest, as it not only gives an overview of the Partidas but, at 367, it 
Despite the Comparative Law Bureau's optimism, Las Siete Partidas suffered an extremely long gestation. Again in 1914, the Annual Bulletin lists it as "being published by this Bureau,"131 but a lack of funds delayed the project year after year. ${ }^{132}$ (One can only speculate as to whether the decidedly mixed critical reception of The Visigothic Code played a role in this.) Scott's reaction to the extended delay is interesting. Given his wealth, he easily could have subsidized its publication himself and have had the satisfaction of seeing it in print. Instead, in 1926, Scott made a codicil to his will in which he ordered the executor to use the proceeds of his estate to publish any of his manuscripts that remained unpublished at the time of his death, including " $[\mathrm{t}]$ hose that are in the hands of the Secretary of the Comparative Law Bureau of the American Bar Association."133 Perhaps Scott proceeded in this way because he felt it was the Bureau's obligation to fund the text he had provided to it gratis. ${ }^{134}$ In any case, it was not until 1928, when the Bureau finally decided to supply $\$ 1,000$ of the costs and American law publisher Commerce Clearing House agreed to cover all additional costs, that Las Siete Partidas could be prepared for publication. ${ }^{135}$

Scott did not die until May 30, 1929, ${ }^{136}$ but it appears as if he had nothing to do with the final preparation of his manuscript of Las Siete Partidas. Perhaps he had become less capable of concentrated work by February of 1928 when the funding arrange-

contains the only photo of S. P. Scott I have seen. (The photo appears to be the same one shown on the Thomas Jefferson University website (note 11), and in the German Wikipedia entry (note 10), where it is described as being circa 1890.) Most of the article consists of an address given to the American Foreign Law Association in 1925, but some prefatory material clearly has been added for this publication, subsequent to the decision to publish the translation.

131 "Foreign Laws Translated," Ann. Bul. Comp. L. Bureau A.B.A., 7 (1914), 7, 8.

132 "Las Siete Partidas to be Published at Last," A.B.A. J., 15 (1929), 173. "This translation by Mr. S.P. Scott has been in the hands of the Bureau for a good many years, but it has not heretofore been possible to secure funds for publication." Id.

${ }_{133}$ Samuel P. Scott Codicil (note 109), § 2.

${ }^{134}$ In the 1927 report of the Bureau, Charles Lobingier noted of Scott's translation: "It was delivered to the Bureau upon the condition that it would be published, and we have repeatedly and insistently asked for funds to enable us to publish it, but as yet have been unsuccessful. "Report of the Comparative Law Bureau," Ann. Report A.B.A., 50 (1927), 51,52 .

135 "Report of the Comparative Law Bureau," Ann. Report A.B.A., 51 (1928), 514.

${ }^{136}$ See notes $150-151$ and accompanying text. 
ments were completed, ${ }^{137}$ or perhaps he had long since washed his hands of the matter in disgust at the delay. Whatever the reason, Charles Lobingier, the Bureau's Vice-Chair, supervised the book's proof-reading and wrote the introduction, and John T. Vance, Law Librarian of Congress, created a bibliography for it. ${ }^{138}$ While Scott must have been aware before he died that his translation of the Siete Partidas finally would be issued, he did not live to have the satisfaction of seeing its favorable critical reception and to enjoy some sense of redemption after the substantial negative reaction to The Visigothic Code.

For Scott's Las Siete Partidas was indeed well-received by commentators. Although not all the reviews were rapturous, they were uniformly positive about Scott's translation. One reviewer said that the task had been "accomplished in a most scholarly and painstaking manner,"139 and a native Spanish-speaking jurist opined that "The translator understands the evolution of the idiom perfectly and has accomplished his task as might a Spanish jurisconsult deeply versed in the study of the classics of that language."140

Other reviews tended to contain more about the nature of the Partidas than about the translation itself, but their tone was quite positive. ${ }^{141}$ Even the reviewer who, perhaps unnecessarily, recalled the deceased Mr. Scott's previously ill-received translation of the Visigothic Code, admitted that Las Siete Partidas was a "marked improvement"142 and went on to allow that "In general, Mr. Scott's translation represents a formidable task acceptably executed ... [although] it is not without occasionally questionable renderings . . .."143 It also is a tribute to Scott's translation of the Siete Partidas that it was reprinted not long ago by the respected University of Pennsylvania Press. ${ }^{144}$ This tends to verify the observation in a review of the reprint that "Seventy years on, Scott's translation has proved the test of time . ..."145

${ }^{137}$ See "Report of the Comparative Law Bureau" (note 135).

138 "Report of the Comparative Law Bureau" (note 134).

139 A. S. Aiton, "Current Legal Literature, Las Siete Partidas," A.B.A. J., 18 (1932), 329.

140 A. S. de Bustamante y Sirven, "Las Siete Partidas," Tul. L. Rev., 6 (1932), 328.

${ }^{141}$ F. C. Fisher, "Las Siete Partidas," Hisp. Am. Hist. Rev., 12 (1932),

216; W. M. W. Splawn, "Las Siete Partidas," Georgetown L.J., 20 (1932),

547; E. Wambaugh, "Las Siete Partidas," Harv. L. Rev., 46 (1933), 1054.

${ }^{142}$ Grant (note 119).

${ }^{143}$ Id., 781.

${ }^{144}$ See note 3 above and accompanying text.

145 T. G. Watkin, "Las Siete Partidas," J. Legal Hist., 23 (2002), 171, 172. 


\section{The Civil Code and other translations}

a. Other translations

As was noted above, Scott probably was at work on other translations even before The Visigothic Code was published in 1910. Not only was Las Siete Partidas listed as ready for publication in 1913, but in 1915 the Comparative Law Bureau reported that it had "in hand" manuscripts for not only Las Siete Partidas, but also for The Laws of Ancient Castille, and The Criminal Code of Spain, all by S. P. Scott, and donated to the Bureau by him. ${ }^{146}$ The last two never were published, and appear to have vanished, despite the previously mentioned will codicil ordering their publication if they remained unpublished at the time of his death. ${ }^{147}$ This may be because the proviso applied only "if the officials of that body are willing to surrender them."148 It may well be that the Bureau fully intended to publish the two in question as part of its ongoing translation series and therefore declined to give them to the executor. The relevant codicil clause specifies that nine unpublished volumes were in the hands of the Bureau at that time (November 1926), and it refers separately to the seventeen manuscript volumes of The Civil Law and to his unfinished History of France. ${ }^{149}$ Thus, of the four manuscripts that lay awaiting publication when Scott died, only his translation of the entire Corpus Juris Civilis eventually was published.

b. Scott's death and surrounding intrigue

Scott died in the Scott House on May 29, 1929, at age 83, "after a few days illness with pneumonia." 150 The obituary in the local newspaper noted he was one of the few Hillsboro residents to be listed in Who's Who, recalled some of his earlier activities as a prominent member of Hillsboro society, and said that "In later years he lived the life of a recluse, devoting himself to his literary pursuits."151 Subsequent articles, however, revealed much more

146 "Proceedings of the Comparative Law Bureau, Ann. Report A.B.A., 40 (1915), 882, 883.

147 See note 133 above and accompanying text.

148 Samuel P. Scott Codicil (note 133), § 2.

149 Id.

150 "S. P. Scott Dies on Memorial Day," The News-Herald (Hillsboro) (June 6, 1929), 1. The obituary in an out-of-town newspaper claims that "perhaps the best known of his works was his History of Spain [sic]. "Ohio Historian, Samuel P. Scott, Dies, Hillsboro," The Sandusky Register (May 31, 1929), 9.

151 Id. 
interesting aspects of Scott's reclusive life.

First of all, no one knew the combination to Scott's safe, so it had to be drilled open in the search for his will. ${ }^{152}$ Therein was found a note stating the will was at the Cincinnati Trust Company. Initial reports indicated that his estate amounted to about $\$ 1.25$ million (a huge sum in 1929) and that he had bequeathed only $\$ 75,000$ to his wife, the residue going to the Thomas Jefferson Medical College. ${ }^{153}$ After an inventory and appraisal, the estate was valued at $\$ 1,139,867.154$ Subsequently, the Cincinnati Trust Company was appointed executor over the objection of Scott's widow, Elizabeth. ${ }^{155}$

Here the plot thickens, as evidenced by the next newspaper story title: "Suit for Third of Scott Estate."156 Miss Mary Rhoades, erstwhile secretary to Scott, whom we briefly met above, ${ }^{157}$ sued the Scott estate for $\$ 379,995$, claiming Scott had promised her one-third of his estate if she would work for him. ${ }^{158}$ Rhoades stated that she worked for Scott for sixteen years, assisting not only with his writing and translating, but with his business affairs as well. Rhoades claimed she began training for the position in 1911, and that when she began working for Scott in 1913 "he agreed to pay her $\$ 25$ per month and in May 1914 agreed that if she continued to work for him for $\$ 25$ per month, he would leave her one-third of his estate."159 She further claimed that he repeated this promise to her many times, and that in April of 1929 she drew up for him a codicil reflecting that promise. ${ }^{160}$ Of considerable relevance regarding Scott's later life and work is Rhoades' assertion that "for several years Mr. Scott suffered from paresis [dementia] and was mentally incapable of making a will."161

However, the same article revealed that the attorneys

152 "Provisions of S. P. Scott Will," The News-Herald (Hillsboro) (June 13, 1929), 1.

$153 \mathrm{Id}$.

154 "Allowance of $\$ 25,000$ to Widow," The News-Herald (Hillsboro) (Aug. 22, 1929), 1. Scott's books were appraised at \$7,320. Id. As previously noted, the Kress Foundation later purchased them (but perhaps not all) for $\$ 3,500$. Board of Trustee Minutes (note 106).

155 "Name Executor Scott Estate," The News-Herald (Hillsboro) (July

18, 1929), 1.

156 "Suit for Third of Scott Estate" (note 127).

157 See notes 127 and 128 above and accompanying text.

158 "Suit for Third of Scott Estate" (note 127).

159 Id.

160 Id.

161 "Alleged Codicil to Scott Will," The News-Herald (Hillsboro) (July 17, 1930), 1. 
searching for Scott's will found an affidavit by him stating that:

He had good reason to believe that certain evil-disposed and dishonorable persons may after his death attempt to plunder his estate by presenting some false and fraudulent claims for alleged services or other consideration evidenced by a note, bond, contract, or other promise in writing alleged to have been signed by him and calling for the payment of money, and he declared he has never executed or shall execute such a document, and that if it should be presented for collection, then it is a forgery. ${ }^{162}$

The article also indicated that Mrs. Scott had refused to take under the will (the $\$ 75,000$ left her by S. P.) and would instead elect her statutory share, which would amount to about $\$ 275,000.163$ In the end, the Scott Estate was appraised for tax purposes at $\$ 1,014,128$, with Mrs. Scott receiving $\$ 260,450$, the Jefferson Medical College $\$ 754,128,{ }^{164}$ and Mary Rhoades $\$ 1,000 .{ }^{165}$

Adding yet another soap opera aspect to the Rhoades-Scott story is the fact that in 1914, shortly after Mary S. West, as she was then, started working for Scott, her husband, Charles M. West, sued her mother, Matilda Rhoades, for alienating Mary's affections from him. ${ }^{166}$ A few weeks later, Mary filed for divorce and requested she be restored to her maiden name of Mary S. Rhoades. ${ }^{167}$ This is relevant to our examination of Scott and his work, and not a matter of idle curiosity, because Charles West's complaint alleges his wife's mother practiced "the doctrine of Spir-

162 Id.

163 Id.

164 "Largest Ever Left in Highland County," The News-Herald (Hillsboro) (July 3, 1930), 1. It should be recalled that the Great Depression was underway by this time and most likely diminished the value of the Scott Estate from its initial valuation, which was calculated in August of 1929, before the Black Tuesday stock market crash of October 29, 1929.

165 "Alleged Codicil to Scott Will" (note 161). There are complications that need not be gone into here, but, according to the newspaper account, Miss Rhoades settled the suit she brought against the estate in Cincinnati (Hamilton County) for $\$ 1,000$ then tried to revive it in Highland County. Id. In the Highland County Court of Common Pleas, Judge McBride ruled in favor of the Scott estate attorneys who had demurred to her action, alleging Miss Rhoades's suit did not state facts sufficient to support a cause of action. The judge gave her twenty days to amend her complaint, but there is no indication she did so. "Hear Questions on Scott Estate," The News-Herald (Hillsboro) (Oct. 2, 1930), 1.

166 "Sensational Charges Made," The News-Herald (Hillsboro) (April 30, 1914), 1.

167 “Court News," The News-Herald (Hillsboro) (June 18, 1914), 4. 
itualism, her hypnotic powers, her second Sight, and all the other wild and visionary isms, and fanatical tenets which defendant claims to possess upon his wife," thereby alienating her affections towards him, ${ }^{168}$ and because Scott's library shows that he, too, had an interest in spiritualism, hypnotism, and the occult. 169

It is not clear that Scott and Matilda Rhoades even knew each other, so it would be wrong to succumb to the temptation of conjuring lurid notions of Matilda and her young daughter Mary mesmerizing the aging Scott. However, Hillsboro was a small town, so it seems quite possible that Scott at least knew of Matilda Rhoades and of her interests before he hired Mary in 1913. Certainly Matilida's interests became public knowledge with Mr. West's suit in 1914. In any case, it is reasonable to consider whether Scott's, his secretary's, and her mother's mutual interests in esoteric topics, in addition to his alleged later-life dementia, combined to affect Scott's work in his last years as he prepared The Civil Law.

\section{c. The Civil Law}

The Civil Law remains at the time of this writing the only printed source of an English-language translation of Justinian's Codex and the Novellae Constitutiones. ${ }^{170}$ Scott wrote in the preface to The Civil Law, dated February 11, 1922, that it took him eight years to complete the translation, ${ }^{171}$ which means he started it in 1914 (the year after Rhoades said she began working for him). Hence, he was 68 when he began writing and 76 when he was done. However, many of Scott's notes in Las Siete Partidas refer to passages in various parts of the Corpus Juris Civilis, so he clearly had read and translated a significant amount of the Justinianic compilation before he focused on it as a separate effort. Because we lack any of Scott's correspondence, we do not know how many drafts he may have gone through, whether he showed it to anyone for comment, or whom he may have contacted about its publication. However, we can learn some things bearing

168 "Sensational Charges Made" (note 166).

169 I estimate there were 50-60 titles in his library on these subjects. For instance, of works on such topics by authors whose last name begins with C there are: Capern, Curative Powers of Mesmerism (1851); Carrington, Personal Experiences in Spiritualism (1913); id., Problems of Psychical Research (1914); Coates, Human Magnetism (1907); id., Photographing the Invisible (1911); id., Seeing the Invisible; and Cocke, Hypnotism (1894).

170 See note 1 above for additional discussion. The Civil Law also contains the only English translation of the Opinions of Paulus.

171 The Civil Law (note 1), vol. 1, 49. 
on his translation by examining his library, looking at his previous work, and reading the reviews.

In the only full-length review of The Civil Law, the Roman law scholar W. W. Buckland pointed out that Scott seemed "to have a rooted objection to the use of any modern authority."172 Buckland notes that Scott used older editions of the texts and, in particular, the Kriegel edition of the Corpus Juris, rather than the Mommsen, Krueger, Kroll and Schoell version. ${ }^{173}$ Buckland goes on to give several examples of Scott's use of antiquated texts. A review of Scott's library indeed shows no evidence of his having obtained any of the newer texts Buckland mentions. Scott's failure to use the Mommsen, Krueger, Kroll, and Schoell edition of the CJC is particularly odd inasmuch as his library contained many other works from the late nineteenth century, including Mommsen's Römische Geschichte (Berlin 1888) and Kroll's Procli Diodochi (Leipzig 1899). Given that Scott must have been aware of Mommsen and Kroll, it seems strange he did not know that their edition of the CJC had been received as a substantial improvement on the Kriegel version. Muirhead, in his Institutes of Gaius and Rules of Ulpian (Edinburgh 1880), which Scott owned, refers to Mommsen's edition of the Digest as "the most trustworthy," and notes it is reprinted in his and Krueger's edition of the Corpus Juris, "not yet completed."174 On the other hand, if Scott was relatively isolated from the scholarly community, as it seems he was, and did not subscribe to scholarly journals (see point ii below), perhaps he truly was not aware that he was using antiquated texts for his translation.

172 W. W. Buckland, "The Civil Law," Tulane L. Rev., 7 (1933), 627, 631.

${ }^{173}$ Id. Scott indicates in his preface to The Civil Law that he used Gothofredus's 1663 Amsterdam edition of the CJC and the Fontes Iuris Romani Antejustiniani (Florence 1908) as well. The Civil Law (note 1), vol. 1, 50. In addition to those, Scott's library contained Huschke's Imperatoris Iustiniani Institutionum Libri Quattuor (Leipzig 1868) and Zachariae von Lingenthal's Imperatoris Justiniani Perpetui Augusti Novellae Quae Vocantur (Leipzig 1884) and Appendix ad editionem Novellarum Justiniani (Leipzig 1884). Moreover, he owned many translations of parts of the CJC, but, with two exceptions, he does not show these in his preface in the lists: "This translation has been made from" or "It has been compared with the following authorities." See Appendix 2 for a list of these titles gleaned from his library. If Scott did in fact use any of these translations to inform his own, this also may account for some of its flaws. Interestingly, the catalog of his library does not show that he owned the Spanish translation of the CJC, Cuerpo del derecho civil by Rodriguez de Fonseca, Ortega, and Barcardi (Barcelona 1874).

174 James Muirhead, The Institutes of Gaius and Rules of Ulpian (Edinburgh 1880; repr. Edinburgh 1904), xvii. 
Three other important factors relevant to The Civil Law are obvious from a review of Scott's library.

i. His collection contains relatively little on Roman law and Roman history. Of the approximately 4,200 titles, it appears that only 100 or so are on Roman history and about 50 on Roman law. This is in marked contrast to Justice Blume's much smaller library, which contained several hundred titles on those subjects, scores of them detailed treatises on Roman law. ${ }^{175}$ Given that both Scott and Blume translated the Codex and Novels around the same time, the lack of overlap between their libraries is nothing short of astonishing. Scott was interested primarily in Spain and in the broad sweep of European history, and in Roman law only as it played a role in the other two. He seems to have seen Roman law and Roman-influenced law more as a matter of history and literature, than as functioning sets of legal rules. In his preface to The Visigothic Code, Scott quotes Gibbon's statement that "Laws form the most important portion of a nation's history," and then goes on to write that "from them, more impartially than from any other source, we derive information of the customs, virtues, vices, political ethics, faults, follies, and religious prejudices of a people."176 This cultural-literary approach to the law caused some of the problems critics remarked upon in his translations and which are noted further below.

ii. Another interesting aspect of Scott's library is that it contains no scholarly journals and he appears not to have gone to libraries where he might have used them. This again contrasts with that of Justice Blume, who owned a long run of the Zeitschrift der Savigny-Stiftung für Rechtsgeschichte (romanistische Abteilung), where so much major Roman law scholarship appeared, and who otherwise obtained access to journals for his work. Although Scott lived in the small town of Hillsboro, he was only some 55 miles from Dayton, whose law library was listed in that period as containing one of the "principal foreign law collections in the United States," 177 so it seems he could have chosen to use journals to inform his work. Moreover, he clearly traveled to Philadelphia on occasion and could have used the excellent law

175 See for example the list of materials Blume cited in his annotated Code: "References and Abbreviations in the AJC," in "Annotated Justinian Code" (note 1).

176 The Visigothic Code (note 2), v.

177 See "Principal Foreign Law Collections in the United States," Ann.

Bul. Comp. L. Bureau A.B.A., 6 (1913), 8. 
libraries there to keep up with scholarly journal literature. ${ }^{178}$

iii. The final point to note regarding Scott's library is the relative absence of German-language works in the collection. While Justice Blume, a native German-speaker, stocked his library with many hundreds of volumes on Roman law and history in that language - in which much of the leading scholarship was being done - Scott acquired only some 160 German titles, dictionaries and the like included. A mere six German-language works are included among the 122 authorities Scott includes in his list ("It has been compared with the following authorities") in the preface to The Civil Law. ${ }^{179}$ Most of the relatively little Scott owned on Roman law was in English.

Partially as a result of the factors just discussed, The Civil Law was unsuccessful and generally not well regarded. Buckland's contemporary review of it is a model of honest, but humane, book reviewing. He writes that his examination of the translation shows Scott "had at his disposal an adequate latinity and has produced a version written in an English which can be read with pleasure. But much more than that was needed, and the work cannot be said to satisfy these further requirements" [sc. of an adequate translation, about which Buckland had previously given his opinion]. ${ }^{180}$ Buckland elaborates on what he sees as the most serious problem of Scott's translation, which he characterizes as "the absence of what may be called the automatic recognition of what the text must mean to a Roman lawyer, which, while it gives an admissible rendering of the Latin, as Latin, fails quite to give the real sense of the proposition."181 This comports with my sense that Scott viewed Roman laws mainly as history and literature. Again, this is in stark contrast with the approach of Justice Blume, a long-time jurist who took pains in making his translation to ascertain how the laws in question actually worked in practice.

Buckland's appears to be the only true review of The Civil Law. Other scholars have commented on the work, but it seems that Scott's executor, the Central Trust Company of Cincinnati,

178 The prefaces to both History of the Moorish Empire and The Visigothic Code list Philadelphia as the place of their writing. See History (note 5), vol. 1, vii, and The Visigothic Code (note 2), xliv. Two Philadelphia libraries are listed in that era as being among the "principal foreign law collections." See "Principal Foreign Law Collections in the United States" (note 177), 8.

179 See The Civil Law (note 1), vol. 1, 50-54.

180 Buckland (note 172), 629.

181 Id. 
did not distribute the seventeen-volume work widely to academic journals for review. (According to the executor's final accounting of August 12, 1932, it paid the Johnson and Hardin Company $\$ 21,005.92$ to publish The Civil Law, ${ }^{182}$ so one can see why the executor would have decided not to add to that expense by sending review copies.) A representative sample of remarks about Scott's translation of the CJC are that it is "distinctly poor,"183 notoriously unreliable, ${ }^{184}$ and that it "shows no knowledge of any of the impressive Roman law scholarship made since the middle of the nineteenth century."185 Justice Blume nearly stopped working on his own translation of the Codex when Scott's translation was published, but he later said in correspondence with Clyde Pharr that after he had read one book of the Code "I found what I thought so many glaring mistakes that I concluded to go on with my work."186

However, despite its faults, Scott's translation of the Justinianic corpus has proven to be of some use. Buckland concluded that "while the work cannot be regarded at all a safe guide to the Roman Law, it will, if cautiously used, serve fairly well for the only purposes to which, in the opinion of the reviewer ... a translation of the Roman texts can properly be put."187 (In Buckland's opinion, this purpose is "as a finder and a time saver," since, even in the learned world, few read Latin as quickly as their own language. $)^{188}$ The translation has been used in univer-

182 "Final Accounting," Journal G-1, 242, Highland County Probate Court (1932). Digital image of receipt from the Johnson and Hardin Company, dated July 21, 1932, on file with the author. By way of comparison, one calculation of the equivalent sum in today's dollars is $\$ 358,000$. See "Relative Value of a U.S. Dollar," at Measuring Worth (website).

${ }^{183}$ A. A. Schiller, Roman Law: Mechanisms of Development (The Hague 1988), 31.

${ }^{184}$ O. F. Robinson, Sources of Roman Law (London 1997), 57 n.11.

${ }^{185}$ C. Donahue, "On Translating the Digest," Stanford L. Rev., 39 (1987), 1057, 1062. For another comment, see Q. Breen, “Justinian's Corpus Juris Civilis," Oregon L. Rev., 23 (1944), 219, 224 n.13. For other criticisms made in passing, see M. Hoeflich, "Legal History and the History of the Book: Variations on a Theme," U. Kan. L. Rev., 46 (1998), 415, 424 n.23, and L. de Ligt, "A Philologist Reads the Digest: D. 34,5,13(14), 2-3,” TRG, 66 (1998), 53, 62 n.21.

186 Letter from Fred Blume to Clyde Pharr, June 1, 1933, Blume Collection, H69-10, Wyoming State Archives, Reference, Research and Historical Photo Unit, Wyoming Department of State Parks and Cultural Resources, Cheyenne, Wyoming. See also Kearley (note 16), 538.

187 Buckland (note 172), 632.

188 Id., 628. 
sity classes, ${ }^{189}$ and by some writers, ${ }^{190}$ even though its fatal flaws have kept it from becoming the standard English translation.

\section{Conclusion}

After becoming well acquainted with Samuel Parsons Scott's life and work, I cannot help but conclude that the totality of his contribution should be reassessed. At a minimum, it seems he ought not to be as routinely dismissed as he seems to be. There is no question that his work is marred by an unscholarly laxity. He never entirely left his early roots as a writer for a popular, if educated, audience. He indulged in vast generalizations and failed to document many of his assertions. Scott's apparent isolation from the scholarly community seems to have left him unaware of new findings that would have enabled him to produce better work, and, perhaps most importantly, it cut him off from the benefits of critical pre-publication readings by knowledgeable colleagues. (Justice Blume, in contrast, was connected to other Roman law scholars, ${ }^{191}$ and he welcomed Clyde Pharr's critique of a draft book of his Codex translation, noting that he was accustomed to getting constructive criticism of his Wyoming Supreme Court opinions from other members of the Court, the bar, and law reviews. ${ }^{192}$ )

As one commentator said of Scott, "He translated a great deal, perhaps too much for one man in one lifetime."193 But, at

189 See Breen (note 185), 224 n.14 ("For classes in Roman history it has proved its worth in introducing the students to the Roman system" [after criticizing it in many respects]); Donahue (note 185), 1063 ("In short, Scott was better than nothing, but it was in no way satisfactory" [after noting he insisted students use other translations when available]).

190 See for example Breen (note 185) (in which article Scott's translation is used); J. B. Elkind, "The Aegean Sea Case and Article 41 of the Statute of the International Court of Justice," Revue Hellénique de Droit International, 32 (1997), 285, 325; S. B. Faris, "Changing Public Policy and the Evolution of Roman Civil and Criminal Law on Gambling," UNLV Gaming L.J., 3 (2012), 199, 213 (where the author states in n.79 that she is deviating from Blume's translation and following Scott's "older and less widely accepted translation").

191 For instance, he addressed the Riccobono Seminar on Roman Law in America on the subject of "The Justinian Code and its Value." See Kearley (note 16), 550. On the Riccobono Society, see S. Randazzo, "The Roman Legal Tradition and American Law: The Riccobono Seminar of Roman Law In Washington," RLT, 1 (2002), 123.

192 Letter from Fred Blume to Clyde Pharr, Professor, Vanderbilt University (Jan. 26, 1934) (available in Blume Collection (note 184)). See also Kearley (note 16), 542.

193 Donahue (note 185), 1063. 
this remove, the rather heroic, if often Quixotic, nature of Scott's lonely toil, the scope of his work, and the continuing utility of parts of it - particularly the Partidas — seems worthy of more respect than it has garnered to date.

Appendix 1. Writings of Samuel P. Scott in Chronological Order

1. “Algernon Sidney." Potter's American Monthly 6, no. 53 (May 1876): 333-341.

2. "Granada and the Alhambra." Lippincott's Magazine of Popular Literature and Science (new series) 1, (old series, 27) (May 1881): 425-435.

3. “Cordova." Lippincott's (new series) 2, (old series, 28) (Oct. 1881): 334-344.

4. “Seville." Lippincott's (new series) 3, (old series, 29) (Jan. 1882): 9-20.

5. "Pictures of Andalusia." Potter's American Monthly 18, no. 122 (Feb. 1882): 121-131.

6. "Tunis and Carthage" part 1. Potter's American Monthly 18, no. 125 (May 1882): 481-491.

7. "Tunis and Carthage" part 2. Potter's American Monthly 18, no. 126 (June 1882): 601-610.

8. “Toledo." Lippincott's (new series) 3, (old series, 29) (June 1882): 529- 540.

9. “Sargossa.” Lippincott's (new series) 5, (old series, 31) (Jan. 1883): 113-122.

10. “A National Pastime." The Continent 3, no. 13 (March 28, 1883): 387-396.

11. Through Spain: A Narrative of Travel and Adventure in the Peninsula. Philadelphia: Lippincott, 1886.

12. History of the Moorish Empire in Europe, 3 vols. Philadelphia: Lippincott, 1904; reprinted New York: AMS Press, 1977.

13. "Foreign Legislation, Jurisprudence and Bibliography Spain." Annual Bulletin of the Comparative Law Bureau of the American Bar Association (July 1908): 64-65.

14. —. (July 1909): 144-145, 152-153. 
15. "Spanish Jurisprudence Comparatively Considered.” Annual Bulletin of the Comparative Law Bureau of the American Bar Association (July 1909): 14-25.

16. The Visigothic Code (Forum Judicum). Boston: Boston Book Co., 1910; reprinted Littleton, CO: Rothman, 1982.

17. "Spanish Criminal Law Compared with that Branch of AngloSaxon Jurisprudence." Annual Bulletin of the Comparative Law Bureau of the American Bar Association (July 1910): 6280 .

18. "Foreign Legislation, Jurisprudence and Bibliography Spain." Annual Bulletin of the Comparative Law Bureau of the American Bar Association (July 1910): 201-203.

19. —. (July 1911): 167-168.

20. —. (July 1912): 160-161.

21. —. (July 1913): 112-114.

22. —. (July 1914): 185-186.

23. The Laws of Ancient Castille and The Criminal Code of Spain (unpublished manuscripts), noted in Annual Report of the American Bar Association 38 (1915): 883.

24. "European Literature and Legislation - Spain." American Bar Association Journal 1, no. 2 (April 1915): 164-166.

25. —. 2, no. 2 (April 1916): 275-277.

26. —. 3, no. 2 (April 1917): 265-269.

27. —. 4, no. 2 (April 1918): 207-208.

28. —. 5. no. 2 (April 1919): 301-304.

29. - 6, no. 2 (April 1920): 337-340.

30. —. 7, no. 4 (April 1921): 200.

31. - 8, no. 4 (April 1922): 248-249.

32. — 9, no. 4 (April 1923): 262.

33. — 10, no. 4 (April 1924): 284-285.

34. —. 11, no. 4 (April 1925): 262-262.

35. — 12, no. 5 (May 1926): 339-340. 
36. —. 13, no. 4 (April 1927): 230-231.

37. Las Siete Partidas. Chicago: Commerce Clearing House/Comparative Law Bureau, American Bar Association, 1931; reprinted with modifications, 5 vols. Philadelphia: University of Pennsylvania Press, 2001.

38. The Civil Law, 17 vols. Cincinnati: Central Trust Co., 1931; reprinted, 7 vols. New York: AMS Press, 1973; reprinted 7 vols. Clark, NJ: Law Book Exchange, 2001.

Appendix 2. Translations of Justinianic Works in Scott's Library

1. Bérenger, Alphonse-Marie. Novelles de l'Empereur Justinien Traduites en Français, 2 vols. Metz: Lamort, 1811.

2. Domat, Jean. The Civil Law in its Natural Order, 2 vols. Translated by William Strahan. London: F. Bettenham, 1722.

3. Hunter, William. Systematic and Historical Exposition of Roman Law in the Order of a Code. London: W. Maxwell \& Son, 1876.

4. Hulot, Henri. Les Cinquante Livres du Digeste ou des Pandectes de l'Empereur Justinien, 7 vols. Metz: Behmer \& Lamort, 1803-1805.

5. Muirhead, James. Institutes of Gaius and Rules of Ulpian. Edinburgh: T. \& T. Clark, 1880; reprinted Edinburgh: T. \& T. Clark, 1904.

6. Monro, Charles. The Digest of Justinian, 2 vols. Cambridge: Cambridge University Press, 1909.

7. Ortolan, J. D. E. Explication Historique des Institutes de l'Empereur Justinian . . . , vols. II \& III. 6th ed. Paris: Henri Plon, 1857.

8. Pothier, Robert Joseph. Pandectes de Justinien . . ., 24 vols. Paris: Dondey-Dupré, 1818-1823.

9. Poste, Edward. Gai Institutiones. 4th ed. London: Oxford University Press, 1904.

10. Tissot, Pascal-Alexandre. Douze Livres du Code de l'Empereur Justinien, 4 vols. 2nd ed. Metz: Behmer, 1807-1810. 